PATRYCJUSZ PAJAK

Institute of Western and Southern Slavic Studies University of Warsaw
Images

vol. XXIII/no. 32

Poznań 2018

ISSN 1731-450X

\title{
Early 21st-century Serbian exploitation cinema
}

\begin{abstract}
Pająk Patrycjusz, Early 21st-century Serbian exploitation cinema. „Images” vol. XXIII, no. 32. Poznań 2018. Adam Mickiewicz University Press. Pp. 77-96. ISSN 1731-450X. DOI 10.14746/i.2018.32.07.

Exploitation films are one of the main trends of the Serbian cinema of the beginning of the 21st century, when Serbia enters the second phase of systemic transformation, striving to neutralize the effects of the crisis in the first phase of transformation - towards the end of the 20th century - due to the authoritarian policy of Slobodan Milošević and Yugoslav wars. This non-film context allows better understanding of the phenomenon of these films, which in many respects are a continuation of the cinema of self-balkanization cultivated in the 1990s., and at the same time differ from it, because they do not offer a compromise with difficult transformational reality, but express the need to release the social trauma born of experience of political violence in the Milošević era.
\end{abstract}

KEYWORDS: exploitation film, Serbian film, systemic transformation, pornography, monstrosity

By the most general definition, proposed by David Roche, an exploitation film (also referred to as 'trash' or 'grindhouse') is a work filmed at the lowest cost possible, aiming at generating the easiest profit possible. [1] This economic ambition entails specific artistic consequences. In order to make money whilst investing limited financial resources, exploitation film makers utilize the aesthetics of controversy, scandal and shock, as it attracts the attention of a large number of viewers. Therefore, they utilize - as concluded by Antonín Tesař and Jiří Flígl a method typical of the tabloid press: they provide gaudy, cheap and vulgar sensation, discussing in a simplified manner subjects that are the most desired by a mass audience, primarily violence and sex.[2] They hype them up to an extreme, which often violates cultural taboos.

According to Eric Schaefer's data, the first exploitation films were created in the United States in the 1920 (the term 'exploitation feature' first appeared in the American press in the early 1930s). [3] Interesting-

[1] D. Roche, Exploiting exploitation cinema: an introduction, "Transatlantica" 2015, no. 2, p. 1.

[2] A. Tesař, J. Flígl, Varujte své dĕti! Lákadla filmové exploatace, "Cinepur" 2010, no. 68, p. 2.

[3] Exploitation, which labels the film formula described, means overexposition, which originally referred - as noted by Eric Schaefer - to the garish graphic layout of the posters promoting exploitation films, as well as - by Linda Williams's account - to the intensified use of socially banned or tabooed subjects. Since the 1960 s, exploitation has been associated with exaggeration of formerly banned or tabooed and thereafter merely controversial film subjects. David Roche provides two more semantic contexts for the term discussed - financial exploitation of the audience (who purchase tickets to such films) and exploitation of the film formula (consisting in the maximum utilization of narrative and story patterns by the mass production of films based upon them). E. Schaefer, „Bold! Daring! Schocking! True!”: A History of Exploitation Films, 1919-1959, Durham-London 1999, pp. 3-4; Williams L., Seks na ekranie, trans. 
ly, at the time, they were didactic in character. They taught feminine hygiene and contraception, cautioned against sexual debauchery, and stigmatized drug addiction. Those and similar problems were at the time regarded as morally scandalizing, hence they were often affected by the censorship ban on screening in cinemas. [4] Exploitation film directors presented said problems within a plot that emphasized their sensationalism. This type of cinema remained popular until the 1950s, when its creators gradually abandoned the didactic tone, only emphasizing vulgar sensation. The aforesaid change was influenced by the increasing freedom of speech, intensifying rivalry on the film market, progressive diversification of the cinema audience, and aspirations to attract the largest young audience possible.

The low aesthetic quality of most exploitation films justified branding them as trashy and primitive. Because they were usually produced and distributed on the fringes of cinematography, they were sometimes regarded as a type of independent (created outside of major film studios) and alternative (as compared to mainstream films) cinema. [5] Over the years, some became the object of adoration with a camp tinge, and an inspiration for high-budget and auteur films.[6] Over time, exploitation cinema also developed with increasing dynamism within the mainstream of film production, resulting in broadening and at the same time muddying of the boundaries of the convention; this enforced a partial verification of its initial definition, which had emphasized the low budget, technical primitivism and artistic triteness of the works representing it. The traits listed do not always appear in contemporary examples of exploitation cinema. However, at its unchangeable core remains the tendency to intensely emphasize tabloid topics.

Approximately forty main genres and sub-genres of the exploitation convention can be observed. Some lost popularity or even died out after some time, others are still emerging and gradually taking hold on the film market. Presently, the most popular variants of the genre include cannibal films, zombie films, sexploitation (soft-porno-style

M. Wojtyna, Gdańsk 2013, p. 104; D. Roche, Exploiting Exploitation Cinema: an Introduction, "Transatlantica" 2015, no. 2, pp. 5-6.

[4] In the United States, the said ban was legally sanctioned in the 1930 s by the Hays Code, which remained in effect until the 1960s. However, exploitation cinema developed outside of the mainstream film production and distribution system, thereby circumventing censorship restrictions. In the period from the 1920 s until the 1950s, exploitation films were screened chiefly by traveling cinemas. In the $1960 \mathrm{~s}$ and 1970s, they entered regular distribution, although they were most commonly available in art houses. Since the 1980s, they have also been distributed on video cassettes, and thereafter on DVDs and on the Internet.
[5] Ernest Mathijs and Xavier Mendik argue that within alternative cinema, exploitation films constitute the polar opposite of underground films in terms of artistic ambitions. E. Mathijs, X. Mendik, Introduction. Making sense of exterme confusion: European exploitation and underground cinema, in: Alternative Europe. Eurotrash and Exploitation Cinema Since 1945, ed. E. Mathijs, X. Mendik, London-New York 2004, pp. 3-4.

[6] The exploitation convention is used in some films by such auteur cinema directors as: Pier Paolo Pasolini, Lars von Trier, Michael Haneke, Quentin Tarantino, Tim Burton. 
films), slasher films (about psychopaths who commit serial murders using sharp tools), torture porn movies (films that focus on sadistic tortures), rape and revenge films, monster movies, and carsploitation (about races and car crashes). These and other forms of exploitation cinema are chiefly produced by Western (North American and Western European) culture, although their local variants are also developing in other regions of the world, such as Asia, Latin America and Australia.

In Eastern Europe, works of the type discussed here were rare for a long time, which, following World War II, was caused chiefly by political factors, namely the domination of communist ideology, which, generally speaking, forbade the production of aesthetically and ethically controversial films, as they were incompatible with the purpose of film-making as propagated by it. In countries dominated by real socialism, only isolated works with traces of exploitation were produced. In Serbia, which during the communist period was one of the Yugoslav republics, the first such film was shot in 1970 by Dušan Makavejev, under the title W.R: Mysteries of the Organizm (WR - misterije organizma).

This work was part of a trend called Yugoslav Black Wave, which developed in the 1960 s and early 1970 . Black Wave was characterized by its critical and anti-establishment attitude toward the socialist Yugoslav order and its accompanying political propaganda. In his work, Makavejev asks the question of what role communist ideology attributes to sexual life, and answers it in an avant-garde manner, using collage and performance. He intertwines documentary and fictional parts, collating authentic manifestations of the sexual revolution in the United States with utopian postulates for a sexual revolution in Eastern Europe (in Yugoslavia and the Soviet Union). Bold sex scenes which bring to mind sexploitation, and the splatter finale alluding to them, in which a Soviet figure-skater uses his skate to sever the head of a Yugoslav communist who postulates sexual liberation, reinforces the politically provocative meaning of Makavejev's work, for the director ridicules the communists' hypocritical sexual conservatism, which stands in contrast to the truly revolutionary liberation of man from the weight of traditional culture. State censors banned distribution of the film. This ban was not revoked until just before the fall of communism in Yugoslavia - in 1987.

Later, a trace of exploitation poetics could be found in the thriller Reflections (Već viđeno, 1987), by Goran Marković - a film maker regarded as part of the so-called Prague School, i.e. a group of Yugoslav directors and cameramen who had graduated from the Prague Film School. The film tells the story of a former pianist who works as a music teacher at a community centre, where he falls in love with a young aerobics instructor. The feeling intensifies his latent mental disorders, which drive him to commit a massacre in the woman's home, which is filmed in a slasher-like style. Much like Makavejev's work, Marković's film also has a political meaning, although it is less emphasized and provocative than in W.R. Mysteries of the Organism. The director of Reflections traces the causes of the main character's illness and aggression 
by going back to his childhood, when he witnessed the violence used by the Yugoslav authorities during the introduction of the communist order. This experience left its pathological mark on his psyche.

In both Makavejev's and Markovićs's films, the exploitation elements are used to radicalize the political overtones of the plot. Therefore, they play an important, but not a leading role. As such, neither work can truly be considered a model example of exploitation cinema. Such examples, also characterized by their moderately clear political meaning, appeared later - at the beginning of the 21st century - because the production conditions of the time favoured it. Explaining these conditions requires going back to the 1990s, when Serbia was ruled by a post-communist regime under President Slobodan Milošević, who propagating populist and nationalist slogans - involved his citizens in four Yugoslav Wars: in Slovenia, Croatia, Bosnia and Herzegovina and Kosovo, resulting in economic sanctions imposed on the country by Western states. The wars and sanctions plunged Serbia into an economic crisis, fuelling the development of organized crime, which reached a political scale. The final note of that period, deepening the social collapse of the time, was the bombarding of Serbia by NATO forces during the Kosovo War.

The Milošević era was the first phase of the post-communist systemic transformation in Serbia. At the time, Serbian film-makers could count on little else than the support of private investors, as state film studios, created and operating during the Yugoslav era, had collapsed under the new political and economic conditions. The only state entity which co-financed film-making to a small degree in the $1990 \mathrm{os}$ was Serbian television. Such production conditions meant that the majority of the films at the time were those of the mainstream cinema genres (chiefly comedies and gangster films), as they ensured that the money invested would pay off. Those works were also popular among audiences because they filled a gap left by Hollywood films, which were not distributed in Serbia due to the sanctions enforced upon it by Western countries.

Following the collapse of Miloševićs regime in 2000, Serbian cinema was still financed chiefly by private means, but a newly-established state institution called the Serbian Film Centre (Filmski centar Srbije) also began to support it, giving directors the opportunity to leave the limited circle of popular film conventions. This situation is succinctly described by Jurica Pavičić, who notes that the economic transformations of the time caused the collapse of many cinemas. Others were dominated by the Hollywood repertoire, which returned to Serbia due to the abolishment of the Western sanctions. These circumstances forced Serbian film-makers to seek new artistic solutions which would enable their works to attract the attention of the audience interested chiefly in high-budget works from across the Atlantic. In addition to the support of state-run institutions and competition for the audience, an important factor influencing the condition of the Ser- 
bian cinema was, as argued by Srđan Vučinić, the emergence of digital cameras, the use of which decreased film production costs. As a result of the changes described - after a few difficult years of the new millennium - the number of films being produced increased and their genre palette broadened. At the time, a tendency to rebel against mainstream conventions became apparent among the youngest generation of film makers. They used solutions that had rarely been used in the previous period, such as the exploitation convention, which they utilized, hoping to interest audiences with scandalizing subject matter.[7]

The first exploitation film shot during the period discussed is Dejan Zečevićs T.T. Syndrome (T.T. Sindrom, 2002). It is a slasher taking place in a Belgrade public toilet, turned into a death maze. The people trapped within die in succession by the hand of a psychopath who dismembers their bodies. Dejan Ognjanović notices in the discussed film a trace of inspiration with the works of Dario Argento, which are considered to be part of the giallo genre.[8] In Milan Konjević and Milan Todorovićs Zone of the Dead (Zona mrtvih, 2009), a tanker with a toxic gas which turns people into zombies breaks down at a provincial railway station. The fight against the mutants is led by two American Interpol agents. Srđan Spasojević's A Serbian Film (Srpski film, 2009) became famous as one of the most repulsive films in the history of cinema. Its main character is a renowned porn star who quit his profession and started a family, but returns to pornography, enticed by a generous fee for starring in a particularly degenerate film, which includes paedophilia, snuff and necrophilia. Mladen Đorđevićs The Life and Death of a Porno Gang (Život i smrt porno bande, 2009) also tells a story about pornography - underground pornography, with the added variety of homosexuality and transsexualism. Several actors who are unsuccessful in amateur pornographic films head to the Serbian countryside to give pornographic performances there, and thereafter - for a much larger fee - shoot snuff films which show suicides committed by desperate people.[9]

Another Serbian exploitation film shot at the time - Maja Milošs Clip (Klip, 2012) - is part of the teensploitation genre, which depicts extreme behaviours of young people during adolescence. The main character of the film discussed is a secondary-school pupil from a poor family living on the outskirts of Belgrade.[10] She compensates for her disillusionment with the surrounding reality with provocative sex with

[7] J. Pavičić, Postjugoslavenski film. Stil i ideologija, Zagreb 2011, pp. 50-53; S. Vučinić, Muze u senci istorije. Pregled srpskog filma od raspada SFRJ do danas, "Sarajevske sveske" 2008, no. 19-20, pp. 202-206.

[8] D. Ognjanović, Srpski horror film između metafore i stvarnosti, in: Novi kadrovi. Skrajnute vrednosti srpskog film, ed. D. Ognjanović, I. Velisavljević, Beograd 2008, pp. 39-40. Several years later - in 2016 - Zečević shot another exploitation film (this time in English), titled The Rift (Procep, 2016). In it, he combines elements of science fiction, slasher and a zombie horror film.

[9] Earlier - in 2005 - Đorđević made a documentary titled Made in Serbia (Made in Serbia), dedicated to the condition of the pornographic industry in Serbia. [10] The film was shot in the Sremčica and Kanarevo brdo housing estates. 
sadomasochistic elements, recording her excesses with a smartphone. Milan Todorovićs Nymph (Mamula, 2014)[11] tells a story about two American tourists who are on holiday, sightseeing at a desolate keep on a Montenegrin island, and encounter a nymph who eats human flesh.[12]

The majority of the films discussed were shot at a relatively low cost, which affected - although not in every case - their artistic quality. Works of lower quality, such as T.T. Syndrome, Zone of the Dead and Nymph are close to traditional, aesthetically crude exploitation films. [13] The Life and Death of a Porno Gang, following the underground style, is characterized by greater artistic ambitions. Similar aesthetics, albeit more polished and consequently devoid of underground nonchalance, is presented by Clip. A Serbian Film, which, due to greater financial outlays, was made with great aesthetic care, is a different case. However, due to its exceptionally vulgar contents, it was banned from being distributed in cinemas in eleven countries (including Germany, Spain and France). Clip was similarly banned in Russia (it was only shown at the Saint Petersburg International Film Festival). In Serbia, distribution of none of the aforesaid works was restricted for moral reasons - they were all screened on equal terms with others, although not all of them were popular among audiences.

The leading theme of the works discussed is sadistic or masochistic degradation of the human body. The shock associated with the presentation of said theme is enhanced in most of them (the exceptions being Zone of the Dead and Nymph) by the quasi-documentary and often quasi-amateur stylization of the film footage and narration, known as found footage.[14] Its popularity grew with the increasing general availability of filming equipment (digital cameras, smartphones, industrial cameras) and the ability to easily distribute (on the Internet) the footage recorded with it.

[11] In the original, the film is titled after an Adriatic island off the coast of Montenegro. It is derived from the surname of Lazar Mamula, a Habsburg general of Serbian nationality, who erected a keep on the island in the mid-19th century. In addition, the title is associated with the Serbian word mamiti 'to beguile', which in turn - in the context of the work discussed brings to mind mythical nymphs (or, more accurately, mermaids or sirens), who beguiled sailors with their singing.

[12] To a limited degree, exploitation poetics also become apparent in the films Tilva Roš (Tilva Roš, 2010) by Nikola Ležaić and Panama (Panama, 2015) by Pavle Vučković. In the former, secondary-school pupils from a provincial town commit self-mutilation for the sake of thrill-seeking. An element of sexploitation is contained in the latter, where a well-off Belgrade student enters an intense sexual relationship with a poor girl. Since the late 1980s, numerous amateur, semi-amateur and study exploitations films in the horror or science fiction genre, of short, medium and full length, have also been made in Serbia - as listed by Jovan Ristić and Dragan Jovićević. J. Ristić and D. Jovićević, Izgubljeni svetovi srpskog filma fantastike, Beograd 2014, pp. 53, 57-60, 62-73, 76-106, 114, 118, 125-199.

[13] The similarity of the latter two films to traditional exploitation cinema is also determined by the fact that they were made in English and the main characters are played by actors known from American films of that type.

[14] Western directors of exploitation films began to use found footage as early as in the late 1970s in works which emphasized violence. At the beginning of the 21st century, found footage became a convention which was often used, especially in various types of exploitation horror films. 
The use of the so-called diegetic camera, which - whilst recording the picture - is physically present on the screen (as a prop) and/or implicitly (by playing the footage recorded with it) is the main characteristic of found footage. In works made fully or partly in the found footage convention, the characters use a video camera, digital camera or a smartphone camera, or just use recordings from such cameras or from fixed cameras (chiefly industrial ones). The footage recorded/ played by them become part of the film, resulting in a film-within-a-film effect. Emphasis of the intermediation of the camera being used spontaneously (by witnesses to or participants in the events being filmed) and/or objectively (from a relatively neutral point of view) introduces a sense of authenticity to the situations being recorded, and it is this sense that intensifies the shock when those situations are drastic. The use of the found footage convention also draws attention to the role of audio-visual media in displaying such situations. It also emphasizes the fact that, due to such media playing a big part in the shaping of contemporary social life, some part of said social life takes place in the media world. Found footage sensitizes one to the mutual influences between the media reality and empirical reality.

The value of the shock which may be caused by Serbian exploitation films lies not only in their entertainment value (resulting from the strong emotional excitement aroused in the audience), but also in the reflection they incite, as the screening of events that drastically violate cultural norms reminds viewers of the existence of said standards, making them sensitive to their current state. As such, the films discussed may be interpreted as commentaries to the social situation in Serbia at the beginning of the 21st century. At the time, the country entered the second, more advanced phase of its systemic transformation, for after the collapse of Miloševićs regime, Serbia's isolation from the West ended and its rebuilding, following many years of crisis and NATO bombardments, began. Functionaries of the old regime were removed from their positions, hence political fighting became exacerbated, the most extreme manifestation of which was the assassination of Prime Minister Zoran Đinđić in 2003. The Serbian authorities desired political and economic support from Western countries, but those countries named some terms of their own. One of them - the most awkward for Serbians - was the need to settle accounts for the war crimes committed by their soldiers during the Yugoslav Wars in the 1990s.

Therefore, the road to stabilisation of the country appeared difficult. Nevertheless, Serbia embarked on it, which may be considered a new beginning in its social life, characterized by its contradictions: on one hand, a hope for a better life appeared; on the other, Serbians felt the consequences of the previous decade's crisis and of their country having been stigmatized by Western public opinion, which viewed Serbia from the angle of the Balkanist stereotype. According to it, as mentioned by Maria Todorova and Božidar Jezernik, the Balkans are a 
backward, poor and barbaric region of Europe.[15] The said stereotype formed in the West as early as in the 18th century and has survived until the present day, when it was updated by the Yugoslav Wars. At the time, it began to be associated chiefly with Serbia, as it was the country most often blamed in the West for the unleashing of the aforesaid wars.

In the 1990s, the stereotype discussed was adopted by Serbian directors, such as Emir Kusturica and Srđan Dragojević, who transformed it into a self-stereotype (this phenomenon is called by Jurica Pavičić - after Tomislav Z. Longinović - 'self-balkanisation').[16] The self-balkanisation effect was achieved by Serbians using carnival aesthetics, which enabled them to take an ambiguous position on the Balkanist stereotype. On one hand, they presented it as the original and fascinating, nearly mythical essence of Serbianness. On the other, they put it in ironic brackets, exaggerating its conventionality. Therefore, the Balkanist self-stereotype was perversely elevated and at the same time ridiculed. Consequently, the message of self-balkanisation cinema was as follows: the West sees Serbians as barbarians because they themselves want to be perceived that way. This meaning of self-Balkanist films was peculiarly conformist, as it enabled avoidance of the harshly critical assessment of the 1990s in Serbia. The edge of criticism became blunted by the carnival ambiguity.

At the beginning of the 21st century, self-balkanisation cinema slowly disappeared, although Kusturica still shot films in that poetics.[17] Exploitation cinema continues self-balkanisation in some respects, as it also emphasizes the stereotypical (Balkanist) traits of Serbian culture (primitivism, irrationality, destructiveness). However, it has a different attitude toward them: it neither mythologizes them nor makes ironic remarks about them, but instead vulgarizes them. It rejects the carnival filter which elevated Serbian reality and at the same time ironically distanced itself from it, and applies a naturalistic magnifying glass in order to emphasize its dark parts. Two social metaphors acted as the magnifying glass in it. One is pornography, which, from the point of view of post-communist countries such as Serbia, constituted one of the flagship products of Western culture. To a limited degree (in the form of the periodical press) it was present in Serbia as early as in the late 196os, but it was not until after the fall of communism that it could develop without political restrictions, including in cinema, which

[15] M. Todorova, Bałkany wyobrażone, trans. P. Szymor, M. Budzińska, Wołowiec 2008, pp. 19-55; B. Jezernik, Dzika Europa. Bałkany w oczach zachodnich podróżników, trans. P. Oczko, Kraków 2007, pp. VIII-XIV, 1-40.

[16] T.Z. Longinović, Playing the Western Eye. Balkan masculinity and post-Yugoslav war cinema, in: East European Cinemas, ed. A. Imre, New York-London 2005, p. 46; J. Pavičić, Postjugoslavenski film. Stil i ideologija, Zagreb 2011, pp. 137-180. This term has a similar meaning to the term 'self-exoticism', which
Dina Iordanova uses in a broader and more politically neutral film context. D. Iordanova, Cinema of Flames. Balkan Film, Culture and the Media, London 2001, p. 56.

[17] Namely, the works: Life Is a Miracle (Život je čudo, 2004), Promise Me This (Zavet, lit.: Testament, 2007) and On the Milky Road (Na mlečnom putu, 2016). Another director who used that poetics at the time was Srđan Koljević, who made The Red Colored Grey Truck (Sivi kamion crvene boje, 2004). 
constitutes one of the most extreme examples of the westernisation of Serbian culture.

Pornography as a metaphor describing the social situation in Serbia at the beginning of the 21st century has been discussed, using A Serbian Film as an example, by Toni Kostić.[18] According to Mario Kozina, a similar purpose is served by pornography in The Life and Death of a Porno Gang, although the aforesaid critic does not use the term 'metaphor', but 'analogy'.[19] A metaphorical connection between pornography and the Serbian systemic transformation can also be observed in Clip. The exposition of pornography, commonly associated with liberation from traditional ethical and moral principles, depicts in the discussed films a situation typical of transformations, when a cultural norm which governs social life loosens because its previous political and economic pillars cease to apply and new pillars have not sufficiently formed yet. Such conditions create an anarchistic and egotistic temptation to overstep the norm, and facilitate fulfilment of the temptation.

Slavoj Žižek believes pornography to be highly conventionalized in terms of aesthetics.[20] Therefore, when considering it as a metaphor which describes liberation from the old, socialist, Yugoslav norms during the period of systemic transformation, one must remember that said liberation itself is also standardized in character. In A Serbian Film and The Life and Death of a Porno Gang, its metaphorical reflection is traditional heterosexual pornography. In both films, this merely constitutes the point of departure for pornographic deviation, compared to which it appears as a phenomenon that is within the boundaries of the cultural norm and therefore embodies it. In other words, the pornographization of the norm, which occurred in the first phase of the transformations (in the 1990s), did not signify rejection of the said norm, but merely the lowering of its standards. It is deviant forms of pornography that led to negation of the norm, which in the works discussed is metaphorically associated with the social situation in the second phase of the transformations - at the beginning of the 21st century.

Therefore, in Spasojević's and Đorđevićs films, the collapse of the cultural norm is illustrated by the collapse of the pornographic norm. In this metaphor, it is not the unseemly and calculated sale of the intimacy of one's own body that violates the norm, but the betrayal of the rules of this sale for the sake of greater profit, which necessitates sale of one's own life. Pornography of the body becomes supplanted by the pornography of death. The characters in both films descend to the lowest level of degradation, crossing successive circles of pornographic hell. They

[18] T. Kostić, Postmoderni film strave kao balkanski žanr: Srpski film Srđana Spasojevića, "Hrvatski filmski ljetopis" 2012, no. 69, pp. 133-134.

[19] M. Kozina, Život i smrt porno bande, "Hrvatski filmski ljetopis” 2010, no. 62, p. 181.
[20] S. Žižek, Camera Shy, Blah, Blah, Blah, The Bafler April 2013, no. 22, <https://thebaffler.com/odds-andends/camera-shy-blah-blah-blah-blah-blah-blah> (accessed: 22.11.2017). 
replace the sex act, performed in traditional porn, with authentic rape of socially marginalized, abandoned and miserable people (orphans in A Serbian Film, suicides in The Life and Death of a Porno Gang), until they ultimately share their fate, committing self-abuse. Serving the role of executioners, they become their own victims. In this vision, the freedom brought by systemic transformation in Serbia proves to be self-destructive - in it, a man loses his own humanity because of the unbridled need for consumerist satisfaction (heightened at the time).

Using the pornography metaphor, Spasojević and Đorđević present the degeneration of the Serbian patriarchal tradition in the times of transformation. The socially dominant position of a male, essential to this tradition and symbolically represented in both films by the main (heterosexual) stream of pornography, devolves into a degenerate extremity. In A Serbian Film, the "ordinary" sexual dominance of a man over a woman gradually degenerates, until it finally takes the form of rape of one's own family - wife and child. This form of criticism of patriarchalism is associated by Toni Kostić with criticism of the political system of Serbia at the beginning of the 21st century. According to him, pornography makers in Spasojevićs work embody the political system - they have power over the bodies and souls of porn stars, who embody common citizens in the interpretation discussed. The system not only rapes (violates), but also encourages or - if necessary - forces them to actively participate in rape (violations).[21] In fact, as mentioned by Shaun Kimber, this is how the director himself interprets his own film, stressing that citizens become violated by the authorities chiefly in the mental sense, as it is at the authorities' command that they, as if hypnotized, do what they do not want to do. Referencing Ivana Kronja's opinion, Kimber associates this interpretation with the subject of male violence as compensation for Serbian men's frustration. Present in Serbian cinema as early as in the 1990s and intensified in $A$ Serbian Film, this violence was born in response to the weakening of social authority due to the multifaceted crisis which men were unable to cope with during the transformation period.[22]

The director of The Life and Death of a Porno Gang does not so much criticize as defy Serbian patriarchalism. In his film, porn stars cultivate an alternative, liberal lifestyle, resembling life in a hippy commune, in which various sexual orientations (heterosexuality, homosexuality, transvestitism) enjoy equal rights. As concluded by Mario Kozina, members of the actors troupe aim to disseminate sexual liberty among their morally conservative Serbian countrymen. They want to fight provincial patriarchal conservatism using provocation that consists in transgression of sexual habits, hence their porn performances

[21] T. Kostić, Postmoderni film strave kao balkanski žanr: Srpski film Srđana Spasojevića, "Hrvatski filmski ljetopis" 2012, no. 69, pp. 137-140, 142-143.
[22] I. Kronja, The Aesthetics of Violence in Recent Serbian Cinema: Masculinity in Crisis, "Film Criticism” 2006, vol. 30, no. 3, p. 34; S. Kimber, Transgressive edge play and Srpski film/A Serbian Film, "Horror Studies" 2014, vol. 5, no. 1, pp. 110-111. 
are cabaret-like, camp, carnival-like in character.[23] Eventually, the situation forces the porn stars to return to a patriarchal "normalcy", which - much as it does in A Serbian Film - assumes a degenerate, self-destructive form (the porn stars are first battered and raped, and thereafter film suicides on request, committed in a cruel manner by men who, in two cases, are the head of families, embodying patriarchal values). They also commit one murder, that of a local criminal and rapist.

Rape turning into snuff in Spasojević's and Đorđevićs films brings to mind the rapes and crimes committed by all sides of the conflict during the Yugoslav Wars, as well as the authoritarian and criminal practices under Miloševićs rule.[24] This association is supported by references to the aforesaid experiences contained in both works. In A Serbian Film, the porn-making crewmen wear black uniforms which resemble the uniforms of paramilitary groups. In The Life and Death of a Porno Gang, the porn stars fall victim to the violence of armed countrymen, and thereafter shoot snuff films on the pattern of those made during the Yugoslav Wars.

The rape committed by the authorities and by the citizens manipulated by them, deep-rooted in the patriarchal tradition and therefore culturally sanctioned, originated - as both directors suggest - in the Milošević era. In the second phase of the transformations - as Serbia opened to the West - it was hidden behind the mask of modernity. Earlier, in the 1990s, the West, blaming Serbia for unleashing the Yugoslav Wars, imposed sanctions upon it and thereafter bombarded, becoming a global enemy to Serbians (as opposed to the local enemies - Croats, Bosnians and Kosovar Albanians), while at the same time embodying the prosperity they dreamed of. At the beginning of the 21st century, the relations between the West and Serbia normalized. However, due to political and wartime reasons, they remained ambiguous, although this ambiguity lost its earlier contradictory nature to perversion, which is reflected in Spasojevićs and Đorđevićs films. In A Serbian Film, the brutal porno film is made with an American distributor in mind. In The

[23] M. Kozina, Život i smrt porno bande, "Hrvatski filmski ljetopis” 2010, no. 62, pp. 180-181.

[24] In this context, it is worth mentioning the concept of pornographic genocide, propagated by Catharine A. MacKinnon with reference to rapes committed on women by Serbian soldiers during the wars in Croatia and Bosnia and Herzegovina. The pornographic nature of the aforesaid acts is determined - according to the American scholar - by their mass scale, methodicalness and exceptional cruelty, as well as by the fact that some of them were filmed and distributed on video cassettes. Vesna Kesić argues with said concept, accusing MacKinnon of superficiality, which leads to scientifically unjustified generalisation and stigmatisation of only one side of the conflict. Ivana Kronja's thesis on the symbiosis between pornography and political propaganda in Serbian tabloid press published during the systemic transformation period is analogous to the concept discussed, albeit better documented. C.A. MacKinnon, Turning rape into pornography: postmodern genocide, in: Mass Rape: The War against Women in Bosnia-Herzegovina, ed. A. Stiglmayer, Lincoln-London 1994, pp. 187-216; V. Kesić, A Response to Catharine MacKinnon's article "Turning Rape into Pornography: Postmodern Genocide", "Hastings Women's Law Journal" 1994, vol. 5, no. 2, pp. 267-280; I. Kronja, Politics as Porn: The pornographic representation of women in Serbian tabloid and its role in politics, in: Stereotyping: Representation of Women in Print Media in South East Europe, ed. N.M. Bamburić, T. Jusić and A. Isanović, Sarajevo 2006, pp. 187-216. 
Life and Death of a Porno Gang, the snuff films are made at the request of a German businessman.

In both films, the Western clients (not shown in A Serbian Film and represented by the German in The Life and Death of a Porno Gang) appear as two-faced benefactors. They tempt Serbians with generous remuneration for satisfaction of their obscene desires, which are forbidden in the Western world. In Serbia, their realisation is possible, as the rules of the civilized world do not apply there. It is a country of morally unrestricted consumerism - anything can be purchased and sold there. In Spasojevićs and Đorđevićs works, violation of cultural taboos, to which Serbians became accustomed during the Yugoslav Wars and Miloševićs rule, becomes their article of exportation.

The war in the countries of former Yugoslavia has ended. However, as suggested by Spasojević and Đorđević, the West has developed a taste for Balkan violence, shown in the 1990 os by war correspondents, and desires its continuation, so that it may still safely - via visual means only - commune with that which does not occur in the Western world, much as a viewer of pornographic films uses them to satisfy sexual desires he cannot fulfil in real life. Wartime and authoritarian violence finds its continuation in film adaptation, where it devolves into its essence: torture. Therefore, the rape committed by the West on Serbia was done "with velvet gloves" - not by participation in it, but through encouragement of it and remotely relishing in it. Therefore, both films also tell the story of the pornographic attitude of the West toward the Balkans.

The pornographic metaphor enables Spasojević and Đorđević to examine the social outcomes of the symbiosis between the remnants of nationalist populism and the harbingers of capitalist liberalism in fine, albeit distorted details. Nationalist populism flourished in the 1990 s among the ruins of socialist Yugoslavia. In the second phase of the transformations, following the political turnabout, it was not as useful as before. However, the ambitions, frustrations and complexes aroused by it still resonated within the Serbian society. In these conditions, increasing consumerist demands introduced by capitalist liberalism assumed an aggressive form. Boris Buden believes capitalism in post-communist countries to be "more capitalist than its Western original, and thus more flexible, more ruthless, wilder, one that, in short, has freed itself from socialist restraints and restrictions, and most importantly, from state-institutionalized forms of social solidarity, to a much greater degree". [25] Serbia, as interpreted by the creators of A Serbian Film and The Life and Death of a Porno Gang, constitutes an extreme example of the phenomenon described by Buden.

Pornography, perceived as one of the flagship products of Western culture, is associated with sexual liberty and the ability to easily experience consumerist pleasure. However, in a reality infected with

[25] B. Buden, Strefa przejścia. O końcu postkomuniz-

$m u$, trans. M. Sutowski, Warszawa 2012, p. 63. 
the degrading and brutal experiences of the Milošević era, it assumes the opposite meaning, becoming synonymous with enslavement and suffering. Therefore, the films discussed criticize not only the cynical attitude of the West toward Serbians, but also the attitude of Serbians themselves, who are willing to sell not only their lives, but also their deaths, in exchange for being allowed participation in the longed-for capitalist consumerism. Assuming the role imposed upon them by the West, they commit self-abuse for show. As interpreted by Spasojević and Đorđević, the modernisation brought by the systemic transformation in Serbia is merely superficial, as it hides the social regression which mostly affects people who are on the margins of the transformations, symbolized in A Serbian Film by the orphanage and in The Life and Death of a Porno Gang by the poor and backward countryside.

The pornographic metaphor also appears in Clip, although it assumes a different form. The main character of the work directed by Miloš is pandering to her boyfriend's sexual whims in order to gain his love. She fancies herself an object of male lust not only by appropriately stylising her appearance and behaviour, but also by recording intimate moments of her life with a smartphone. Consequently, she commits self-pornification, which constitutes an extreme case of the exhibitionistic/voyeuristic/narcissistic need to be seen - including by oneself - typical of modern times. Every moment becomes unique once it is recorded on film, which favours bolstering the self-esteem of the person recording it. The mediatisation of individual identity has the best effects when it involves intimate or extreme situations, as those attract attention the strongest. In Clip, sex does not give the young heroine sufficient pleasure unless it is documented via media means as an achievement to show off. It only gains the desired meaning once it turns into a porno film.

Analysing Milošs film, Jovana Đurović notes an analogy between young people's maturing and systemic transformation, which is, in her opinion, a society's maturing to enter a new stage of development. She also remarks that in traditional films about the social initiation of the youth, the rules existing in the adult world serve as a point of reference for the aforesaid process - their acceptance means completion of the initiation. In the transformation period, the rules change, hence the adult world becomes unstable, consequently ceasing to be a reference for young people, particularly when, as is the case in Clip, it is the world of the lower classes of society, for whom the transformation period was an especially difficult experience.[26] As suggested by Aleksandar S. Janković, the difficult situation of the aforesaid environment is presented in Clip so that it is treated as an outcome of not so much the transformation process as of the communist period.[27]

[26] J. Đurović, Kultura mladih u tranziciji: analiza filmova „Tilva Roš” $i$ „Klip”, "Reč. Časopis za književnost i kulturu, i društvena pitanja” 2012, no. 85/31, pp. 197-198.
[27] A.S. Janković, Redefinisanje identiteta (Istorija, zablude, ideologije u srpskom filmu), Beograd 2017, p. 46. 
In Milošs film, young people do not manifest their individuality by rebelling against the older generation, but against an indolent and unstable reality, which is a problem of the older generation as well. They escape to the media world of vulgar and kitschy pop-culture, which propagates worship of thrills and unrestrained consumerism, in which one is not only a consumer, but also the consumed, hence in order to find a place for oneself in that world one also needs to present oneself as an object of consumption. The model example of such an attitude is found by the characters of Clip in the music trend called turbo-folk, which was born in post-communist Serbia, harmonising in the 1990 os with the military and nationalist rhetoric of the Milošević regime, and eventually compensating for the political weakness of the state in the cultural field at the beginning of the 21st century. The indirect reference to the Milošević era through music is considered by Dijana Jelača to be a manifestation of post-remembrance, which emerges in the lives of the young generation portrayed in Milošs work. [28]

Jovana Đurović stresses that turbo-folk consolidates in Serbia the traditional patriarchal social ideals, which affirm male domination. According to the Serbian film expert, the main character of Clip accepts these ideals and is attempting to face up to them at any cost, which is necessary for her social initiation. The title of the film refers to her dream to be a woman like those from a turbo-folk video clip. She identifies with singers who in their works propagate the stereotype of a woman serving a man, satisfying his needs and consequently affirming him in his masculinity. By recording it with a smartphone, the heroine, as stressed by Đurović, fetishizes her own body.[29] She attempts to view herself in the same manner men do, in order to satisfy their desires better, for she realizes that they derive pleasure not only from having sex, but also from fetishistic observation of a female body. She brings those attempts to the pornographic extreme, which reaches its masochistic climax in the ending of the film (she is battered by her boyfriend in an act of violence to which she herself has provoked him).

The girl's attitude represents a yearning for a patriarchal authority who would provide her with emotional and economic security. Her family life lacks such an authority (her father is seriously ill and the household is supported by her mother). She finds one in turbo-folk. Much like A Serbian Film and The Life and Death of a Porno Gang, Clip depicts the vulgar face of the patriarchal tradition, which during the times of transformation - confronted with the weakening of the institution of a family (in all three films, family erodes) - succumbs to the worship of strength and consumerism, deep-rooted in kitschy manifestations of the pop-culture.

[28] D. Jelača, Dislocated Screen Memory. Narrating Trauma in Post-Yugoslav Cinema, Basignstoke 2016, 205.
[29] J. Đurović, Kultura mladih u tranziciji: analiza filmova „Tilva Roš” $i$ „Klip”, “Reč. Časopis za književnost i kulturu, i društvena pitanja” 2012, no. 85/31, pp. 233-241. 
The other social metaphor used in Serbian exploitation films is monstrosity, usually defined as a combination of opposing traits, which, as argued by Noël Carroll, contradicts cultural norms and therefore arouses negative feelings, ranging from uneasiness and anxiety, fear and revulsion, to terror. [30] Monstrosity constitutes an essential attribute of fantasy and - in consequence - of horror. Fantasy is equated with horror by Roger Caillois, although the term 'horror' is broader, encompassing not only fantastic forms of monstrosity, but also empirical ones (hence A Serbian Film and The Life and Death of a Porno Gang may also be considered horror films, although the monstrous characters and situations created in them are not fantastic in character).[31] The category of exploitation fantasy includes T.T. Syndrome, Zone of the Dead and Nymph.

The transformation period was also monstrous in character, metaphorically speaking, as traces of the old order (socialist and Yugoslav) coexisted in it with harbingers of the new order (capitalist and liberal). In the aforesaid films, the monstrosity of the period is enhanced by the presence of traces of historical eras even older than communism. All of them have a destructive impact on the transformational present. Dejan Zečević sets T.T. Syndrome in a public toilet, which is located in Belgrade's Kalemegdan fortress, built in the early Middle Ages and thereafter modernized periodically. During the Turkish occupation, which lasted, with several breaks, from the 16th to the 19th century, a Turkish bathhouse operated for some time where the public toilet is now. Setting the slasher there brings to mind the Balkanist stereotype, according to which Balkan cruelty constitutes a legacy of the Asian mentality, which people of the Balkans soaked in during the era of Turkish rule over the area. In Zečevićs film, the stereotypically viewed Ottoman past is evoked by the coarse communist past, also not without its own violence factor, and by the transformational present, of which a gloomy picture is also painted (the characters intend to purchase drugs from a dealer in a squalid public toilet).

In T.T. Syndrome, the monstrosity of the transformation results from revival of a past that should be dead. The Ottoman and communist past (the communist one in a broad range - from the 1950 s to the 1980s) pulsate within the walls of the medieval fortress. The public toilet proves to be a place of the accumulation of time, which does not elapse. Here, a person reverts to the primal biological sources of their existence, symbolized by excrement - sources evil by nature, as they lack moral restrictions (in the communist era, a mother kills her newborn in the toilet). This interpretation of the location discussed is justified by the fact that beneath the toilet is a sewage pit dating back to an ancient chaos. Therefore, the contemporary Serbian reality is based - as appears from the proposed interpretation of the film - upon shaky foundations.

[30] N. Carroll, Filozofia horroru albo paradoksy uczuć, trans. M. Przylipiak, Gdańsk 2004, pp. 54-66.
[31] R. Caillois, Od baśni do science fiction, trans. J. Lisowski, in: Odpowiedzialność i styl. Eseje, R. Caillois Warszawa 1967, pp. 31-37. 
It is constantly in danger of reverting to that which is primal, chaotic, primitive and which revealed its presence in times of misfortune for Serbia, during the Turkish occupation and in the communist era, of which the director emphasizes two crucial moments: the years 1958 and 1982. The former date is associated with the end of the brutal repressions against political enemies, seen chiefly in Stalin's supporters. 1982 brings to mind the time following Josip Broz-Tito's death (he died in 1980) and the resulting political thaw after the 1970s, when nationalist- and liberal-oriented political enemies were being repressed. The film is set chiefly in 2001 - this is another crucial year. Following the period of Miloševićs rule, which was difficult for Serbians, the second phase of transformations begins. Each of the dates listed signifies a new beginning in Serbian history. In T.T. Syndrome, this moment is interpreted literally: this is when the abyss of the sewage pit opens, reversing history to its inhumane beginnings.

In Zone of the Dead, references to the historical and political background are even more distinct. The breakout of a zombie epidemic in Pančevo, a provincial Serbian town, is associated with the Turkish heritage, as it was the Turks who brought the plague which turns people into zombies to Serbia in the distant past. The epidemic is revived in the late 1980 o - in the final period of existence of socialist Yugoslavia (it is important to note that at the time, the Socialist Republic of Serbia, which is part of Yugoslavia, is ruled by Slobodan Milošević). At that time, labourers unearth by chance a corpse from the Turkish occupation era, infected with the disease. The epidemic is curbed, but the Yugoslav government uses it to produce biological weapons, which they test during wars in the Middle East and Africa (this is a reference to Yugoslavia's participation in the Non-Aligned Movement, an organisation of Third World countries).

The main plot of the film takes place at the beginning of the 21st century - during military exercises conducted jointly by American and Serbian troops, which should be interpreted as an ironic reference to the change in the relationship between the United States and Serbia from antagonistic (as mentioned, at the end of the 2oth century, NATO planes, chiefly American, bombarded Serbian targets in Kosovo and Serbia) to moderately open. A tank car with the biological weapon, manufactured during the days of socialist Yugoslavia, is unsealed, which is also significant, as a result of a trivial argument between an American soldier and a Serbian policeman (the scene described reminds one of the still flickering American-Serbian animosity). The political thesis of the film is as follows: it is not the United States that is Serbia's true enemy, but the "toxic" legacy of the past in the form of communism, which constitutes a reference to the Ottoman times and was continued under Milošević's rule. Serbians are unable to deal with said "poison" on their own: they succumb to it easily. Therefore, they are condemned to accept Americans' help (zombies are fought by two American Interpol agents, supported by a Ukrainian, whose character also has political 
significance, as he symbolizes liberation from the communist diktat of the Soviet Union era and suggests the need for Serbians to free themselves from the influence of the Yugoslav legacy).

In Nymph, the (ancient, fascist and communist) past is also monstrously revived in the present. The symbolic reservoir of times past is, much as it is in T.T. Syndrome a historic building: a fortress erected in the mid-19th century by the Habsburg army on a Montenegrin island. During World War II, when Montenegro was occupied by Italians and thereafter by Germans, the fortress served as a prison for political enemies (chiefly communists). The director of the film references ancient traditions by using the myth of a nymph (mermaid/siren), made famous by Homer in The Odyssey. The nymph, who combines beauty and cruelty, embodies the stereotype of the monstrous, mysterious and archaic Balkans as a place isolated from the world and following its own rules. In Todorović's film, human flesh is being fed to her by a former officer of the Yugoslav army, who has remained a fanatical communist even after the collapse of Yugoslavia.

In this context, the nymph also symbolizes the hidden monstrosity and hypocrisy of the communist regime, which once propagated idealistic and modern values (democracy, justice, liberty, etc.) whilst also dealing with its political enemies in a barbaric manner. Much as the nymph lures men with her beautiful singing to feed on them later, the communists beguile Yugoslavs with their promises of paradise on earth so that they can politically manipulate them. In Todorović's film, the contemporary, capitalist paradise on earth is the coast of Montenegro, which is stylized as a land like from a travel brochure. The old fortress on the island adds unique variety to that landscape. It also constitutes a forbidden place, where various stages of the past have survived, overlapping and consequently assuming a monstrous form.

The relation between the past and the present is interpreted by the directors of T.T. Syndrome, Zone of the Dead and Nymph in a spirit of cultural genetics, which is in fact typical of the horror genre. According to it, past events repeat themselves in the present; therefore, the nature of history is the constant return of the same phenomena. Progress proves to be superficial, for it is merely limited to technology, not mentality. In the works discussed, the ancient, medieval, Ottoman, fascist, communist and Milošević past influences the present by means of fate, often hidden behind a modern mask, which falsely suggests severance of the past. This vision of history serves to support the Balkanist thesis that the politically-motivated tendency to commit monstrous violence is repeated by heredity in the Balkans. This also extends to the transformation period, which constitutes another new beginning in the history of Serbia, meaning a literal return to the beginning, to that which is the most primal, fundamental and lasting in said history. The demons of the past who return then demand a settling of accounts. Only then will it become possible to face toward the future; such is the meaning that may be attributed to the films analyzed. 
Similarly to The Life and Death of a Porno Gang, one of the main signs of the systemic transformation in Zone of the Dead and Nymph is the presence of foreigners who have come to Serbia from the West. However, whereas the German businessman in Đorđevićs film represents an immoral, neo-colonial and capitalist force, cynically encouraging Serbians to materialize the Balkanist stereotype deep-rooted in the past in a self-destructive manner, the Americans from Milan Konjević's and Milan Todorovićs's films serve the opposite role. Admittedly, they do contribute to the escalation of the bloody events that signify the destructive influence of the past on the present, but they do much more to fight that influence, setting an example for Serbians, who wish to sever ties with the stereotypical phantoms that continue to haunt them.

Films based upon the pornography metaphor and those based upon the monstrosity metaphor alike are a good reflection - due to the specific character of the exploitation convention - of the brutal influence of politics on the life of Serbians in the systemic transformation era; film exploitation, by feeding upon the motives which reveal the primitivism of the human nature, indicates the relation between political facts and the individual and collective primal impulses stimulated by them. In this spirit, exploitation cinema diagnoses Serbian society as one that has survived the Milošević era, but suffered trauma resulting from the political violation committed upon it not only by the authoritarian authorities, but also by Western countries, which marked Serbia with the stigma of the Balkanist stereotype, which then demonized the influence of various stages of the Balkan past on the Balkan present. The devaluation of human life, to which this violation leads, is depicted in the discussed films by extreme objectification of a person, which consists in reducing them to corporeality in its consumerist (sexual and food) meaning.

Interestingly, the films discussed lack direct references to the Milošević era; these are allusive or merely implicit. Such film references to traumatic collective experiences are called 'allegoric' by Arthur Lowenstein. The American film expert explains this phenomenon using the example of horror films which reference the experiences of World War II, the Holocaust, the atomic bombings of Japan, and the Vietnam War. These films do not focus on the aforesaid events, but on their non-obvious effect on the present. They tell the story of how the echo of traumatic past resonates within the current reality.[32] Consequently, they encourage the audience to face the trauma, providing them with a safe temporal distance from its source.

A reverse phenomenon occurs in the case of traumatic events which take place in the present. Their allegoric film interpretation consists in finding an analogy for them in the past (Lowenstein provides the example of the terrorist attack on the World Trade Center

[32] A. Lowenstein, Shocking Representation. Historical Trauma, National Cinema, and the Modern Horror

Film, New York 2005, pp. 1-16. 
in 2001 and a film on the Vietnam War, shot at the same time, which implicitly references this attack).[33] Films of this genre suggest that traumatic experiences similar to contemporary ones occurred before and were overcome at the time, hence there is a chance to succeed at it again. When proposing allegoric interpretation of such works, one must remember that it is not always an immanent part of them - it often depends on circumstances unrelated to the film, which encourage the aforesaid interpretation.

One may interpret Serbian exploitation films in a similar, allegorical, manner. In A Serbian Film, The Life and Death of a Porno Gang and Clip, the trauma of the 1990 os is reflected by and extended into events which take place at the beginning of the 21st century. In T.T. Syndrome, Zone of the Dead and Nymph, it also touches upon the beginning of the new century, but its primeval source lies in various periods of the past more distant than the 1990s. This traumatic - albeit stressed merely as an allegory - trait of Serbian exploitation cinema constitutes the essence of the difference between exploitation cinema and self-balkanisation cinema, which depicts the Balkanist stereotype as a norm to be accepted, as it mythologizes it (emphasizes its invariability) and makes ironic remarks about it (provides a semblance of distance toward it). Meanwhile, exploitation cinema, naturalistically vulgarizes it by presenting its most extreme and thus trauma-inducing manifestations. It depicts this stereotype not as a norm which must be compromised with, but instead as an excess which causes shock or disgust. As a consequence, exploitation cinema induces disagreement with Balkanism, provoking thoughts about truth and the manipulation of truth taking place under the pressure of the current political situation.

Buden B., Strefa przejścia. O końcu postkomunizmu, trans. M. Sutowski, Warszawa 2012

Caillois R., Od baśni do science fiction, trans. J. Lisowski, in: R. Caillois, Odpowiedzialność $i$ styl. Eseje, Warszawa 1967

Carroll N., Filozofia horroru albo paradoksy uczuć, trans. M. Przylipiak, Gdańsk 2004

Đurović J., Kultura mladih u tranziciji: analiza filmova „Tilva Roš” $i$ „Klip”, “Reč. Časopis za književnost i kulturu, i društvena pitanja” 2015, no. 85/31

Iordanova D., Cinema of Flames. Balkan Film, Culture and the Media, London 2001

Janković A.S., Redefinisanje identiteta (Istorija, zablude, ideologije u srpskom filmu), Beograd 2017

Jelača D., Dislocated Screen Memory. Narrating Trauma in Post-Yugoslav Cinema, Basignstoke 2016

Jezernik B., Dzika Europa. Bałkany w oczach zachodnich podróżników, trans. P. Oczko, Kraków 2007

Kesić V., A Response to Catharine MacKinnon's Article "Turning Rape into Pornography: Postmodern Genocide", "Hastings Women's Law Journal" 1994, vol. 5, no. 2

[33] Ibidem, pp. 177-188. 
Kimber S., Transgressive edge play and Srpski film, "A Serbian Film, Horror Studies" 2014 , vol. 5 , no. 1

Kostić T., Postmoderni film strave kao balkanski žanr: Srpski film Srđana Spasojevića, "Hrvatski filmski ljetopis" 2012, no. 69

Kozina M., Život i smrt porno bande, "Hrvatski filmski ljetopis" 2010, no. 62

Kronja I., Politics as porn: the pornographic representation of women in Serbian tabloid and its role in politics, in: Stereotyping: Representation of Women in Print Media in South East Europe, ed. N.M. Bamburić, T. Jusić, A. Isanović, Sarajevo 2006

Kronja I., The aesthetics of violence in recent Serbian cinema: masculinity in crisis, "Film Criticism" 2006, vol. 30, no. 3

Longinović T.Z., Playing the Western Eye. Balkan masculinity and post-Yugoslav War Cinema, in: East European Cinemas, ed. A. Imre, New York-London 2005

Lowenstein A., Shocking Representation. Historical Trauma, National Cinema, and the Modern Horror Film, New York 2005

MacKinnon C.A., Turning rape into pornography: postmodern genocide, in: Mass Rape: The War against Women in Bosnia-Herzegovina, ed. A. Stiglmayer, Lincoln-London 1994

Mathijs E., Mendik X., Introduction. Making sense of exterme confusion: European exploitation and underground cinema, in: Alternative Europe. Eurotrash and Exploitation Cinema Since 1945, eds. E. Mathijs, X. Mendik, London-New York 2004

Ognjanović D., Srpski horror film izmedu metafore i stvarnosti, in: Novi kadrovi. Skrajnute vrednosti srpskog film, eds. D. Ognjanović, I. Velisavljević, Beograd 2008

Pavičić J., Postjugoslavenski film. Stil i ideologija, Zagreb 2011

Ristić J. Jovićević D., Izgubljeni svetovi srpskog filma fantastike, Beograd 2014

Roche D., Exploiting Exploitation Cinema: an Introduction, “Transatlantica” 2015, no. 2

Schaefer E., „Bold! Daring! Schocking! True!”: A History of Exploitation Films, 1919-1959, Durham-London 1999

Tesař A., Flígl J., Varujte své dĕti! Lákadla filmové exploatace, “Cinepur” 2010, no. 68

Todorova M., Bałkany wyobrażone, trans. P. Szymor, M. Budzińska, Wołowiec 2008

Vučinić S., Muze u senci istorije. Pregled srpskog filma od raspada SFRJ do danas, "Sarajevske sveske" 2008, no. 19-20

Williams L., Seks na ekranie, trans. M. Wojtyna, Gdańsk 2013

Žižek S., Camera Shy, Blah, Blah, Blah, “The Bafler” April 2013, no. 22, <https:// thebaffler.com/odds-and-ends/camera-shy-blah-blah-blah-blah-blah-blah> [accessed on: 22.11.2017] 